

\section{Disease suppression in cress and sugar beet seedlings with frass of the Black Soldier Fly (Hermetia illucens)}

Hellen Elissen ${ }^{1}$, Mirjam Schilder ${ }^{1}$, Joeke Postma ${ }^{1} \&$ Rommie van der Weide ${ }^{1}$

1 Wageningen University \& Research

This study was carried out by the Wageningen Research Foundation (WR), Business Unit Field Crops and was commissioned and financed by the PPP Biobased valorisation of manure and digestate AF-17052b. This project is financially supported by the Dutch Topsector Agri \& Food. Within the Topsector, private industry, knowledge institutes and the government are working together on innovations for safe and healthy food for 9 billion people in a resilient world. WR is part of Wageningen University \& Research, the collaboration of Wageningen University and Wageningen Research Foundation.

Wageningen, December 2019

Report WPR-816

WAGENINGEN 
Elissen, H., M. Schilder, J. Postma \& R. van der Weide, 2019. Disease suppression in cress and sugar beet seedlings with frass of the Black Soldier Fly (Hermetia illucens). Wageningen Research, Report WPR-816. 21 pp.; 6 fig.; 3 tab.; 8 ref.

This report can be downloaded for free at: https://doi.org/10.18174/515047

Summary: This report describes two bioassays for testing disease suppression by BSF frass in an agricultural soil with two crops: sugar beet (Beta vulgaris) and cress (Lepidium sativum). In the bioassay with beet, soil was infected with the plant-pathogenic fungus Rhizoctonia solani while in the bioassay with cress, soil was non-infected or infected with the plant-pathogenic fungus Pythium ultimum. Both concentrations of the BSF frass ( 7.5 and $15 \mathrm{~g} / \mathrm{kg}$ soil) proved to be useful as soil application, leading to good plant emergence and growth of sugar beet and cress plants. The highest concentration of BSF frass ( $15 \mathrm{~g} / \mathrm{kg}$ soil, both as total product) had a large fertilizer effect. In experiments with cress without addition of Pythium (i.e. with only natural soil infections), disease suppression with BSF frass was found. In all tests, keratin was added as a positive control treatment, which had a higher disease suppression effect than BSF frass but comparable fertilizer effects.

Keywords: black soldier fly, BSF, frass, disease suppression, bioassay, sugar beet, cress, Pythium ultimum, Rhizoctonia solani, Hermetia illucens

(c) 2019 Wageningen, Stichting Wageningen Research, Wageningen Plant Research, Business Unit Field Crops, P. O. Box 430, 8200 AK Lelystad, The Netherlands; T +31 320291 111; www.wur.eu/ plant-research

Chamber of Commerce no. 09098104 at Arnhem

VAT NL no. 8065.11.618.B01

Stichting Wageningen Research. All rights reserved. No part of this publication may be reproduced, stored in an automated database, or transmitted, in any form or by any means, whether electronically, mechanically, through photocopying, recording or otherwise, without the prior written consent of the Stichting Wageningen Research.

Stichting Wageningen Research is not liable for any adverse consequences resulting from the use of data from this publication.

Report WPR-816

Photo cover: Mirjam Schilder 


\section{Contents}

$\begin{array}{ll}\text { Preface } & 5\end{array}$

$\begin{array}{ll}\text { Summary } & 7\end{array}$

$\begin{array}{llr}1 & \text { Introduction } & 9\end{array}$

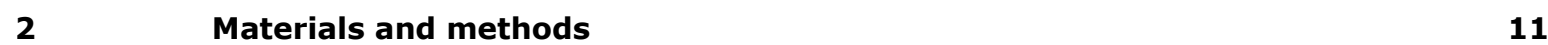

2.1 Materials 11

2.2 Methods 11

$\begin{array}{llr}3 & \text { Results and discussion } & 13\end{array}$

3.1 Sugar beet with $R$. solani $\quad 13$

3.2 Cress with and without P. ultimum 14

3.2.1 Cress without $P$. ultimum 14

3.2.2 Cress with $P$. ultimum 15

4

Conclusions

17

Recommendations $\quad 19$

$\begin{array}{ll}\text { References } & \mathbf{2 1}\end{array}$

$\begin{array}{lll}\text { Annex } 1 & \text { BSF frass analysis } & 23\end{array}$ 



\section{Preface}

In the Netherlands, there are surpluses of manure and digestates/biogas slurries (digested manure and residual flows), which represent a negative value. At the same time, these residual flows contain valuable ingredients for the production of biomass (as raw material for food and feed products), for improving soil quality and for energy production. The number of feasible business cases in which the residual flow is upgraded has so far been limited. This is due both to the efficiency of the technologies used and the legislation and regulations related to the residual flows.

Recent information from research, scientific literature and companies provides new starting points for a biobased valorization of manure/digestate streams and improving the efficiency of anaerobic digestion. The innovative aspect of our research is the cultivation of new types of biomass on the residual flows and the use of the conversion products to improve anaerobic digestion. This involves the use of separated manure and digestate products for the cultivation of mushrooms/fungi, worms, insects, specific bacteria and aquatic biomass. The resulting biomass can be further refined and marketed as food, feed and bio-based feedstock. There are also processed manure and digestate products that are valuable as fertilizer products for soil and plant growth, as substrate for improvement of anaerobic digestion or for export/use besides in agriculture. This gives a new interpretation to obligatory manure processing.

The aim of this project is to further explore and substantiate/test these ideas on lab and practical scale, leading to a proof of principles for new bio-based upgrading methods for manure and digestate that can be used in conjunction to better close cycles and/or sell outside regular agriculture.

Bottlenecks in legislation and regulations are explored and put on the agenda. Key figures are also calculated that are necessary for assessing sustainability (e.g. costs, environmental effects) and for supporting legislation (e.g. minerals, food safety).

The livestock sector gains insight into the possibilities of biobased valorisation and better marketing of their most important residual flows. For the SMEs involved, this research provides proof of principle for their technology and input in their business cases. The combined effects of the technologies provide new knowledge, methods and research directions for science. In a social context, the use and upgrading of manure and digestates in other ways also contributes to the transition to a circular bioeconomy with an efficient and sustainable agri-food sector.

More information:

- http://www.acrres.nl/en/projecten_acrres/biobased-valorization-of-manure-and-digestate/

- Rommie van der Weide: rommie.vanderweide@wur.nl, +31320291631

- Hellen Elissen: hellen.elissen@wur.nl, +31320291223

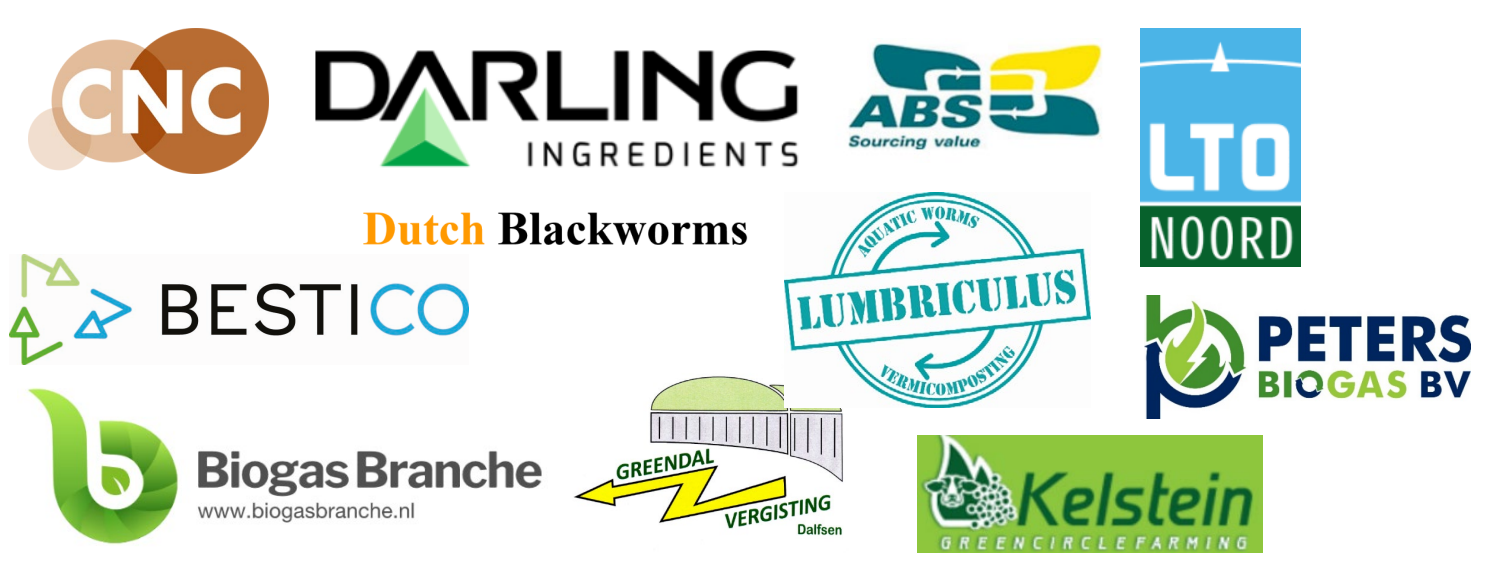




\section{Summary}

This report describes two bioassays for testing disease suppression by BSF frass in an agricultural soil with two crops: sugar beet (Beta vulgaris) and cress (Lepidium sativum). In the bioassay with beet, soil was infected with the plant-pathogenic fungus Rhizoctonia solani while in the bioassay with cress, soil was non-infected or infected with the plant-pathogenic fungus Pythium ultimum. Both concentrations of the BSF frass ( 7.5 and $15 \mathrm{~g} / \mathrm{kg}$ soil) proved to be useful as soil application, leading to good plant emergence and growth of sugar beet and cress plants. The highest concentration of BSF frass (15 g/kg soil, both as total product) had a large fertilizer effect. In experiments with cress without addition of Pythium (i.e. with only natural soil infections), disease suppression with BSF frass was found. In all tests, keratin was added as a positive control treatment, which had a higher disease suppression effect than BSF frass but comparable fertilizer effects. 


\section{Introduction}

During the production of BSF (black soldier fly, Hermetia illucens) larval faeces are excreted, so-called BSF frass or compost or digestate or residue. Salomone et al (2017) show an overview of the main inputs and outputs for their LCA (life cycle analysis) of food waste bioconversion by BSF larvae (Table 1).

Table 1 Overview of inputs and outputs of a food waste bioconversion process by BSF larvae (From: Salomone et al, 2017).

\begin{tabular}{lll}
\hline Description & Unit & Amount \\
\hline Input & & \\
Food Waste & $\mathrm{t}$ & 1 \\
Transport & $\mathrm{tkm}$ & 24.3 \\
Pruning waste & $\mathrm{kg}$ & 5.5 \\
Water & $\mathrm{kg}$ & 61.1 \\
Electric energy & $\mathrm{kWh}$ & 12.9 \\
Output & & \\
Compost & $\mathrm{kg}$ & 334.6 \\
Dried larvae & $\mathrm{kg}$ & 29.6 \\
$\mathrm{CO}_{2}$ & $\mathrm{~kg}$ & 16 \\
$\mathrm{CH}_{4}$ & $\mathrm{~g}$ & 51.2 \\
\hline
\end{tabular}

It is clear that insect frass is one of the main outputs of the process. This frass contains nutrients, such as N, P and $\mathrm{K}$, but also the polysaccharide chitin, which mainly originates from shed integuments of the BSF larvae (Temple et al, 2013). The composition of the larval frass (e.g. N, P, K, DM/OM content) will however depend on the type of substrate fed, as can be seen in Oonincx et al (2015) in which BSF larvae were fed with three different types of manure. Salomone et al (2017) mention the following characteristics of the frass: a low humidity value of $25.7 \%, \mathrm{pH} 6.95$, a well-balanced average NPK content of $1.49 \%, 0.98 \%$, and $1.03 \%$ respectively, comparable with other organic manures and easy storage, packing and transport qualities without requirements for further transformation or stabilization processes. Toxic and essential metal concentrations fell within fertilizer limits. They found it an excellent bio-fertiliser without pre/post treatments. Kebli and Sinaj (2017) concluded the same based on organic matter, NPK and microelements content such as $\mathrm{Cu}$ and $\mathrm{Zn}$ and greenhouse experiments on three types of soil and two crops, ryegrass and lettuce. In addition to these 'regular' fertilizer values of the frass added value of the frass is also expected from its chitin content. Zahn (2017) tested the effect of BSF frass on growth of spring onion and concluded that the frass has potential as a viable biofertiliser and suggests to do longer term growth experiments with higher replication numbers to prove a significant effect on plant growth, due to the potential presence of high microbial biomass, chitin, growth hormones and soil enzymes. Spranghers et al (2016) found a chitin content of BSF prepupae reared on different wastes ranging between 56 and $67 \mathrm{~g} \mathrm{~kg} / \mathrm{DM}$. It is, up till now, not clear what is the chitin content of the BSF frass, since commercial products and research papers merely mention that the frass contains chitin, but not its concentrations.

According to several authors, disease suppressive properties of soils can be enhanced by the addition of chitin rich products. Several authors mention suppression of plant-parasitic fungi (e.g. Korthals et al, 2014; Postma and Schilder, 2015) and nematodes (e.g. Oka, 2010). The idea is that because chitin is present in nematode egg shells as well as in most plant-pathogenic fungal cell walls soil application of chitinous materials will increase the number of chitinolytic microorganisms and chitinase activity in the soil, which in turn has an adverse effect on the nematodes and fungi present (Oka, 2010). 
The bioassays described in this report were done to test the disease suppression (the fungal species Rhizoctonia solani and Pythium ultimum) by BSF frass in an agricultural soil with two crops: sugar beet (Beta vulgaris) and cress (Lepidium sativum). 


\section{$2 \quad$ Materials and methods}

\section{$2.1 \quad$ Materials}

BSF frass was obtained from Bestico BV (Berkel en Rodenrijs, the Netherlands). The frass had been dried overnight at $60{ }^{\circ} \mathrm{C}$ prior to transport for hygienisation purposes. The composition of the frass was analysed by Eurofins (Graauw, the Netherlands) (Appendix I) and had a dry matter percentage of $42.1 \%$. Nitrogen and phosphate concentrations in the dry matter were $37.41 \mathrm{~g} \mathrm{~N}$ and $24.36 \mathrm{~g} \mathrm{P}_{2} \mathrm{O}_{5}$ per $\mathrm{kg}$ respectively.

A sandy soil from arable farming which was sensitive to disease development was used (Vredepeel, the Netherlands). Based on the nitrogen concentration, dosages of 7.5 and $15 \mathrm{~g}$ frass/ $\mathrm{kg}$ of soil were applied, which equals $\mathrm{N}$ concentrations of 0.12 and $0.24 \mathrm{~g} \mathrm{~N} / \mathrm{kg}$ soil respectively. Besides the control soil without additions, the addition of feather meal (keratin) was used as reference at a concentration of $1.5 \mathrm{~g} / \mathrm{kg}$ soil, equivalent to $0.2 \mathrm{~g} \mathrm{~N} / \mathrm{kg}$ soil.

The mixed soils were used to evaluate their suppressiveness against Rhizoctonia solani in sugar beet seedlings and Pythium ultimum in cress seedlings. As a control for natural infection in the soil, cress was also grown in the absence of $P$. ultimum inoculum. Table 2 shows the different experimental treatments and bioassays.

Table 2 | Experimental treatments (products) in tests with BSF frass.

\begin{tabular}{|l|c|c|c|c|}
\hline \# of replicates & Control & Keratin & BSF 7.5 & BSF 15 \\
\hline Sugar beet $+R$. solani & 5 & 5 & 5 & 5 \\
\hline Cress & 5 & 5 & 5 & 5 \\
\hline Cress + P. ultimum & 5 & 5 & 5 & 5 \\
\hline
\end{tabular}

\subsection{Methods}

The soil was mixed with each of the three different products (keratin plus two concentrations of BSF frass), and incubated for two weeks at $20^{\circ} \mathrm{C}$. With these treated soils two bioassays were done. Keratin was used since we already know that this product is disease suppressive; several previous experiments showed positive results,

1) Sugar beet with $R$. solani: Per replicate (total 5), 1.3 litres of soil was inoculated in a tank and sown with 22 sugar beet seeds in two rows (every seed at two cm distance). After germination, the soil in front of the tank was inoculated with $R$. solani. The disease progress was scored during 3.5 weeks.

2) Cress with or without $P$. ultimum: Per replicate (total 5) 200 grams of soil was inoculated with or without $P$. ultimum and incubated for two days. Then the soil was divided in two small pots (=two sub replicates), and cress seeds were sown on the surface. After 1 week, the disease was scored (\%) and the fresh weight of the crop was measured in grams.

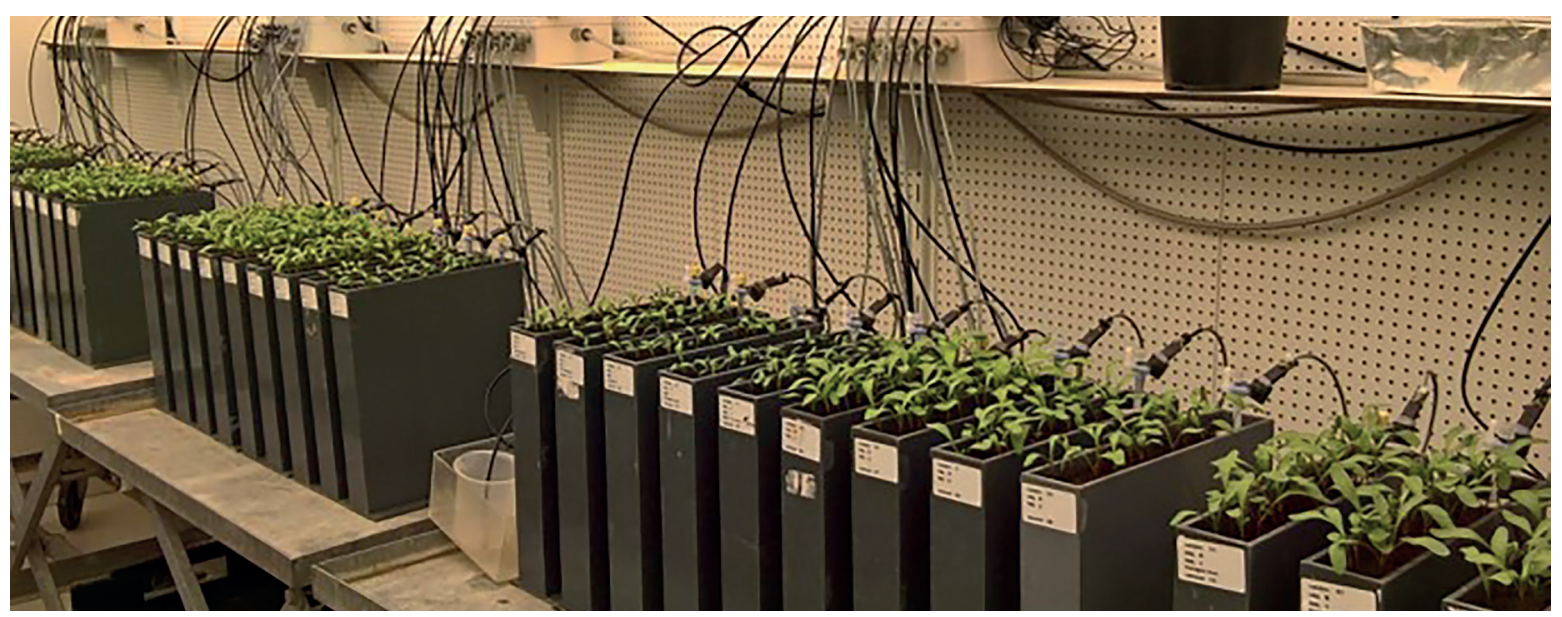

Figure 1 | Sugar beet assay. 


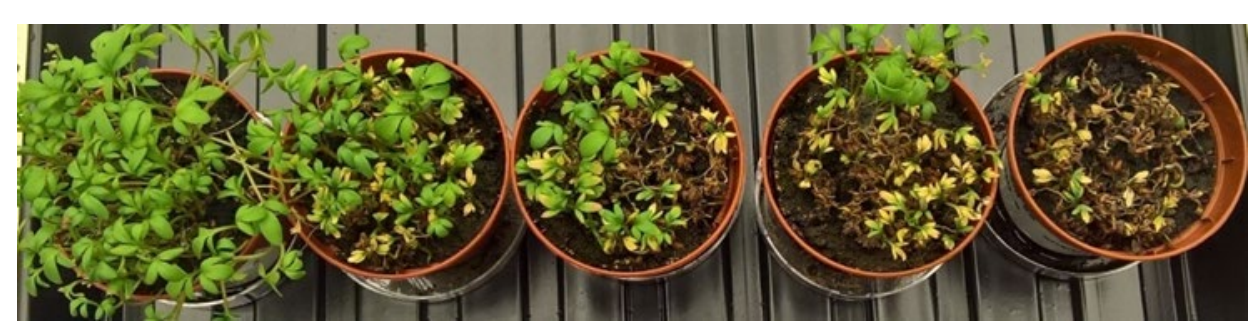

Figure 2 Cress bioassay. 


\section{Results and discussion}

\subsection{Sugar beet with R. solani}

Germination of the seeds was good in all the treatments with products and the control (between 95.5 and $98.2 \%$ on average) and not significantly influenced by the different products (Table 3 ), although plants with frass seemed bigger initially. After germination of the seeds, the pathogenic fungus $R$. solani was added to the first plant in every row. At the end of the experiment ( 24 days after pathogen inoculation) most of the plants got symptoms; percentages of total diseased plants were between 94.5 and $97.3 \%$. There was no significant reduction in the percentage of infected plants in any of the treatments. Since the plants were not only attacked by the inoculated $R$. solani but also by a natural infection present in the soil (possibly Aphanomyces, as symptoms suggested), the progress of the $R$. solani disease from plant to plant could not be scored, which is the normal indicator that we use for soil suppression. The percentage of naturally infected plants was relatively low with BSF 15.

Table 3 | Germination and infection percentages in sugar beet assay. LSD (Least Significant Difference): All differences larger then this LSD are significantly different with, in this case, $95 \%$ accuracy (analysed with ANOVA in Genstat). Results as \% of total plants. Disease percentage is a visual assessment of the surface of plants that are infected (the whole surface of the pot is covered with a standard amount of seeds).

\begin{tabular}{l|c|c|c|c}
\hline Treatments & Germinated seeds & Natural infection & R. solani & Total infection \\
Control & 95.5 & 14.8 & 81.6 & 96.5 \\
\hline Keratin & 97.3 & 19.1 & 78.2 & 97.3 \\
\hline BSF 7.5 & 95.5 & 18.2 & 76.4 & 94.5 \\
\hline BSF 15 & 98.2 & 7.3 & 88.2 & 95.5 \\
\hline LSD $(P=0.05)$ & 5.0 & 11.9 & 14.6 & 8.1
\end{tabular}

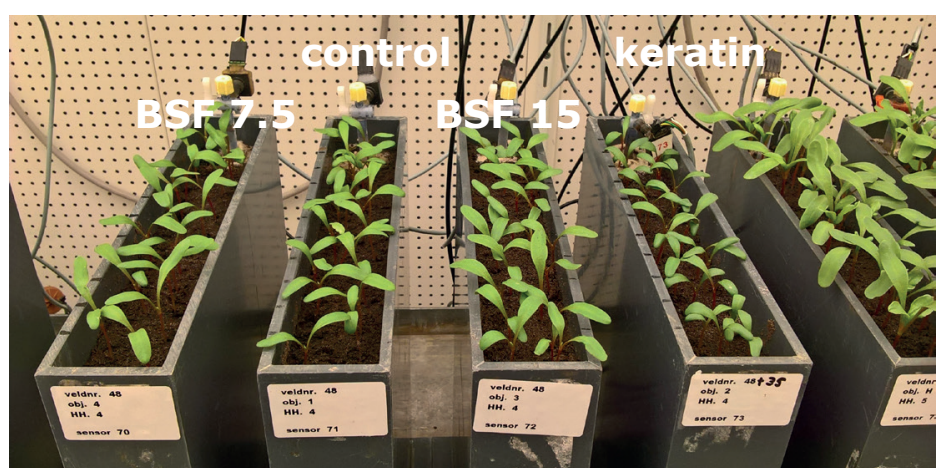

a |

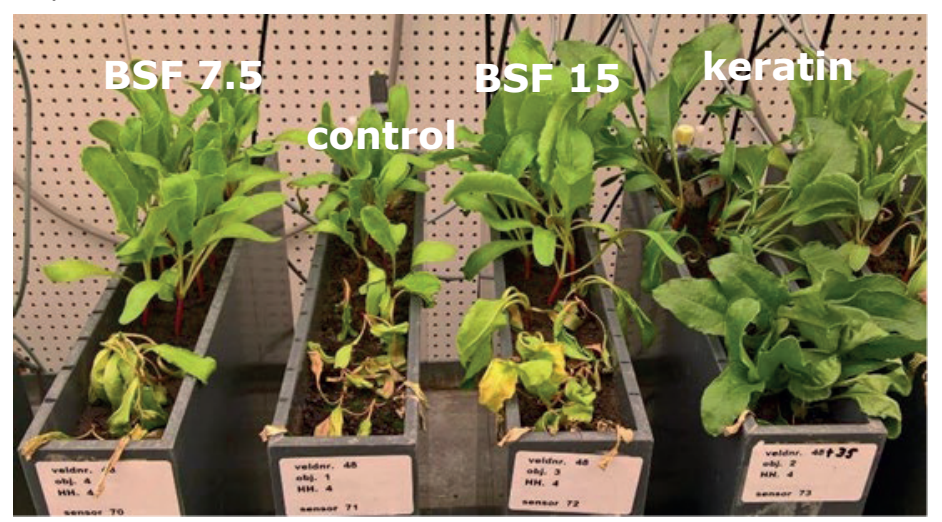

b |

Figure 3 | a Germination of sugar beet plants before $R$. solani infection with different treatments (from left to right): BSF 7.5, control, BSF 15, keratin. b Plant growth after 14 days after $R$. solani infection (same order of treatments as in a). 


\subsection{Cress with and without $P$. ultimum}

In the bioassay with cress clear differences were found between non-infected and infected soils (Figure 4 left and right respectively). However, the effect between the soils with different products was less clear.
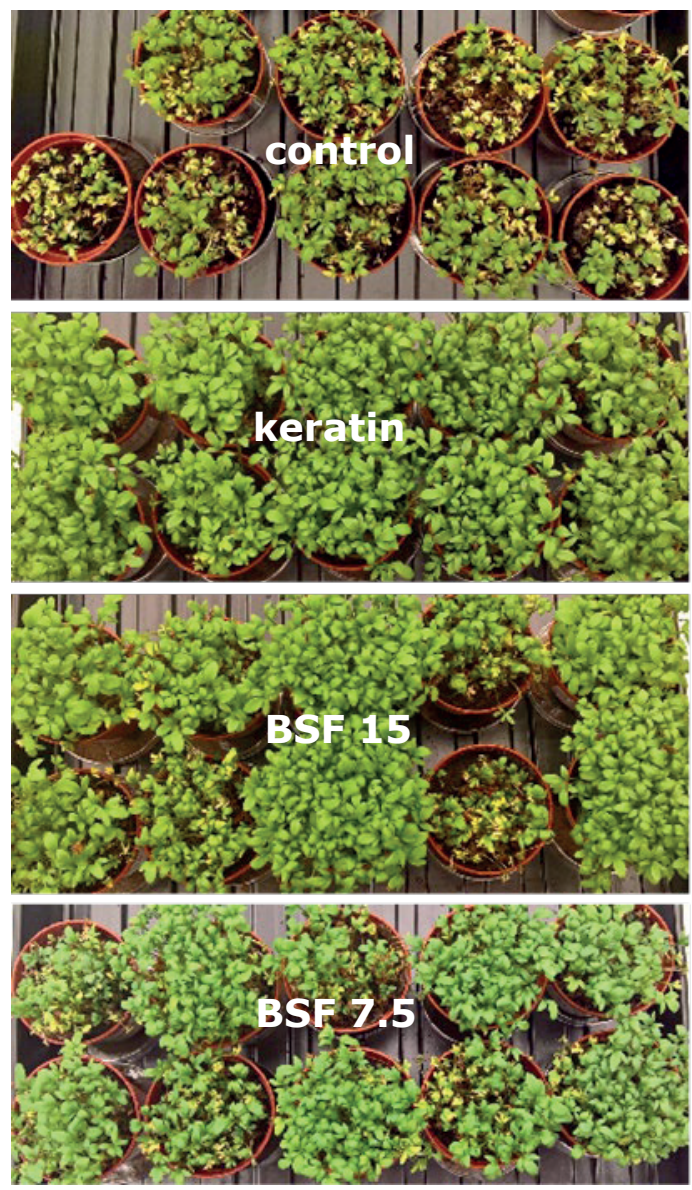
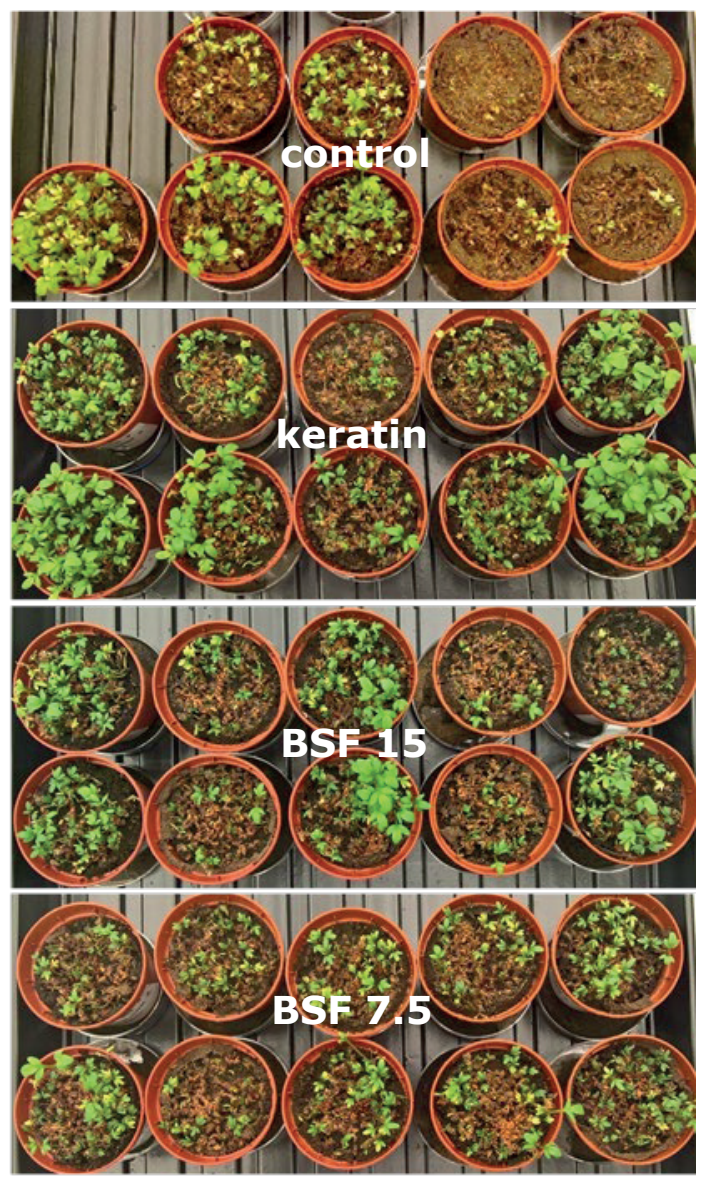

Figure 4 | Growth in cress bioassay with different products without (left column) and with (right column) P. ultimum infection. From top to bottom products were: control, keratin, BSF 15 and BSF 7.5 ( $n=5$ replicates each with 2 pots, except in control experiment: 1 sub repeat missing in both tests).

\subsubsection{Cress without P. ultimum}

In the cress bioassay without $P$. ultimum inoculation the soil appeared to contain a natural infection; on average $54 \%$ of the plants got symptoms in the control (Figure 5). Symptoms were decreased germination and rotting of germinated plants. This was possibly due to a naturally occurring Pythium infection, which leads to similar symptoms. Less plants became infected by this pathogen when BSF frass (both concentrations) or keratin were added (Figure 5). Both additions also led to more crop growth, with a more pronounced effect for BSF 15 and keratin vs. BSF 7.5, which is the result of the number of healthy plants combined with the increased nitrogen availability. $\mathrm{N}$ content of the products was $0.24,0.2$ and $0.12 \mathrm{~g} \mathrm{~N} / \mathrm{kg}$ soil respectively for BSF 15, keratin and BSF 7.5, which is proportional to the total plant weight. 


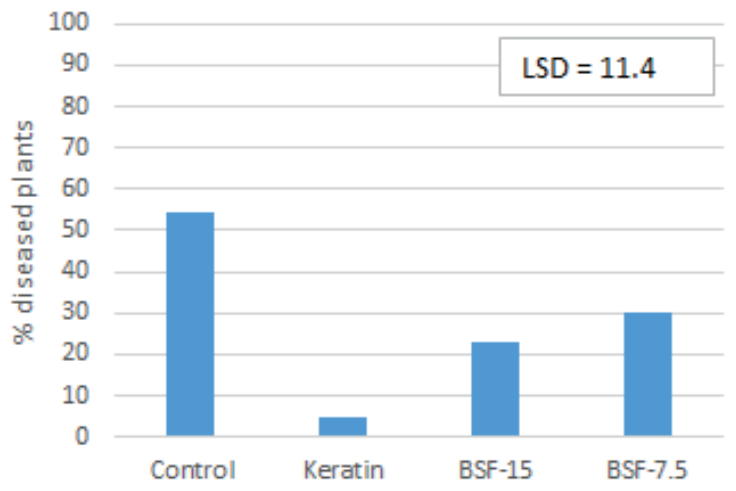

a

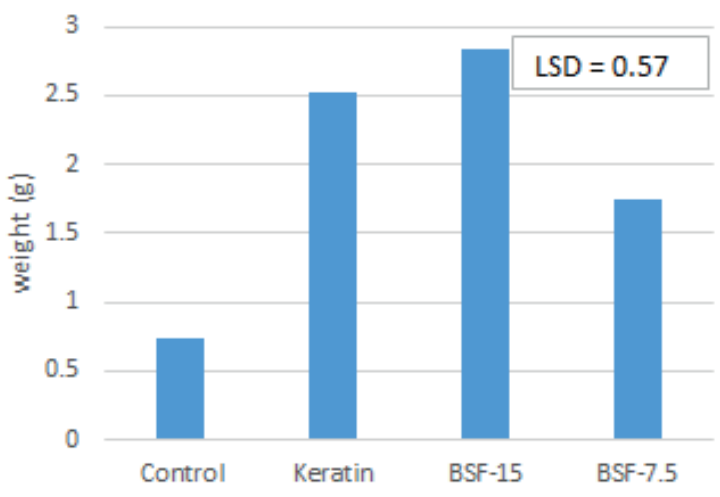

b |

Figure 5 | Plant disease percentage (a) and total plant weight (b) for different products in bioassays with cress without $P$. ultimum infection $(n=5)$ Disease percentage is a (average) visual assessment of the surface of plants that are infected (the whole surface of the pot is covered with a standard amount of seeds). The weight is average total weight of all the plants per pot.

\subsubsection{Cress with P. ultimum}

In the cress bioassay with $P$. ultimum infection a high disease incidence occurred (Figure 6). There was no significant disease suppressive effect found for BSF frass, but there was a small effect for keratin. No significant increase or decrease was found in plant growth induced by BSF frass. We assume that there were too few healthy plants to notice any effect on growth.

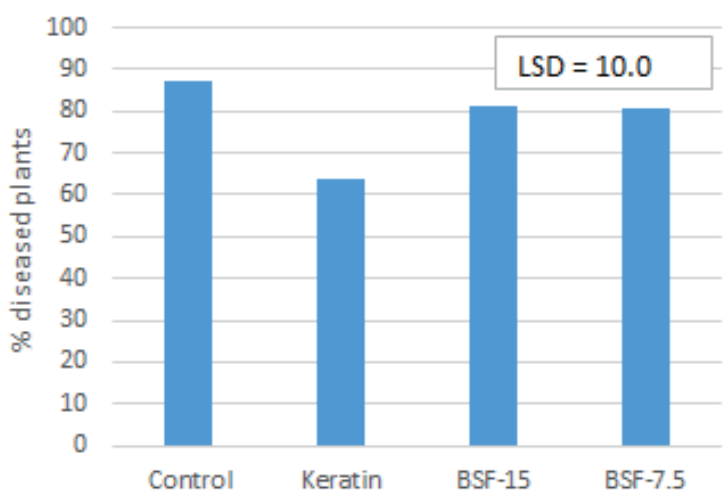

a

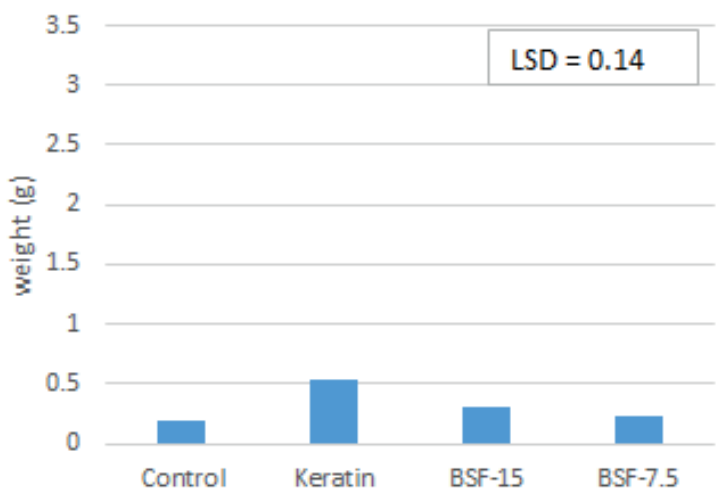

b |

Figure 6 | Plant disease percentage (a) and total plant weight (b) for different products in bioassays with cress with $P$. ultimum infection $(n=5)$ Disease percentage is a (average) visual assessment of the surface of plants that are infected (the whole surface of the pot is covered with a standard amount of seeds). The weight is average total weight of all the plants per pot. 


\section{Conclusions}

Germination of the sugar beet seeds was not reduced by both concentrations of BSF frass additions to the soil. In the sugar beet assay no disease suppression of $R$. solani was found by any of the products. Keratin was used as a reference since this product is known to be able to enhance the disease suppression. We have no explanation for the absence of disease suppression in this experiment, although the presence of natural infections in the soil could have disturbed the bioassay to some extent. Although not significant, BSF 15 led resulted in a relatively low percentage of natural infection.

In the bioassay with cress it was found that natural infections (possibly Pythium species, as similar symptoms, such as decreased seed germination and rot in the juvenile plants, were observed) in the soil were suppressed by BSF 7.5 and BSF 15 (both $\mathrm{g}$ frass/kg soil), which led to less diseased plants. In addition, BSF 15 had a strong fertilizer effect, which led to increased plant growth. After $P$. ultimum infection in the cress bioassay, disease pressure was very high and no suppression was found through both dosages of BSF frass, but positive reference keratin amendment did result in some disease suppression. 


\section{Recommendations}

Based on the experiments with cress in this report, there is suppression of natural infections in soil by Bestico BSF frass and also strong fertilizer effects, most likely due to its macromineral content. More research into the mechanisms behind this disease suppression (for example a test with frass from which chitin is removed compared to a test with regular frass) and analysis of chitin/chitosan components in the frass is recommended, as well as testing the hypothesis of disease suppression under field conditions. Care should be taken to pinpoint possible beneficial effects to the right components. Also, the frass composition and its 'source' (the substrate on which the larvae were fed) should be accurately described since this is highly variable between BSF larvae production facilities. 


\section{References}

Kebli, H. and S. Sinaj, 2017. Agronomisches Potenzial eines natürlichen Düngers aus Exkrementen von Fliegenlarven. Agrarforschung Schweiz 8 (3): 88-95

Korthals, G. W., T.C. Thoden, W. van den Berg and J.H.M. Visser, 2014. Long-term effects of eight soil health treatments to control plant-parasitic nematodes and Verticillium dahliae in agro-ecosystems. Applied Soil Ecology 76: 112-123

Oka, Y., 2010. Mechanisms of nematode suppression by organic soil amendments - a review. Applied Soil Ecology 44, 101-115

Oonincx, D. G. A. B., A. van Huis and J.J.A. van Loon, 2015. Nutrient utilisation by black soldier flies fed with chicken, pig, or cow manure. Journal of Insects as Food and Feed 1 (2): 131 - 139

Postma, J. and M. T. Schilder, 2015. Enhancement of soil suppressiveness against Rhizoctonia solani in sugar beet by organic amendments. Applied Soil Ecology 94: 72-79

Salomone, R., G.Saija, G. Mondello, A. Giannetto, S. Fasulo and D. Savastano, 2017. Environmental impact of food waste bioconversion by insects: Application of Life Cycle Assessment to process using Hermetia illucens. Journal Journal of Cleaner Production 140: 890 - 905

Spranghers, T., M. Ottoboni, C. Klootwijk, A. Ovyn, S. Deboosere, B. de Meulenaer, J. Michiels, M. Eeckhout, P. de Clercq and S. de Smet, 2016. Nutritional composition of black soldier fly (Hermetia illucens) prepupae reared on different organic waste substrates. J Sci Food Agric. 97 (8): 2594-2600 Temple, W. D., R. Radley, J. Baker-French and F. Richardson, 2013. Use of Enterra Natural Fertilizer (Black Soldier Fly Larvae Digestate) As a Soil Amendment. 26 pp.

Vickerson, A., R. Radley, B. Marchant, O. Kaulfuss and T. Kabaluk, 2015. Hermetia illucens frass production and use in plant nutrition and pest management. WO 2015/013826 Al 


\section{Annex 1 BSF frass analysis}

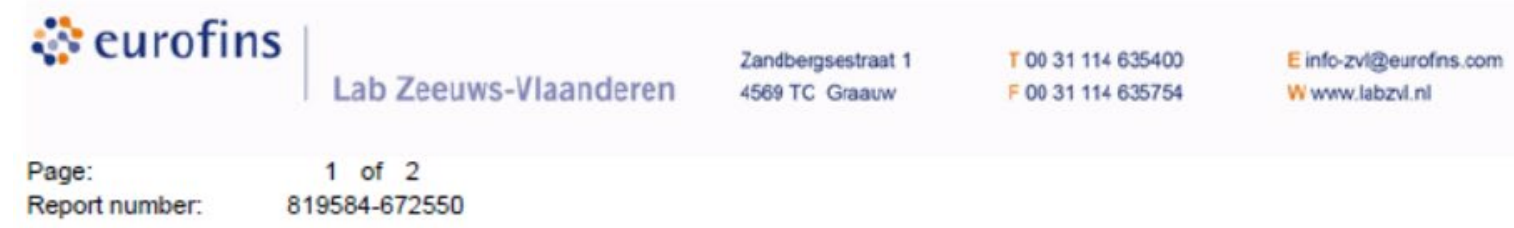

BGM analysis

In order of

Koppert Biological Systems BV

Postbus 155
2650 AD Berkel en Rodenrijs

\section{Relation}

Koppert Biological Systems BV

Postbus 155

2650 AD Berkel en Rodenrijs

$\begin{array}{ll}\text { Sampling date: } & 26-4-2018 \\ \text { Sample taker: } & \text { Opdrachtgever }\end{array}$

Date received: $\quad 2-5-2018$

14-5-2018

2-5-2018

18FE181A BSF compost

\begin{tabular}{llll} 
Sample description: & 18FE181A BSF compost & & \\
\hline Former labnumber: & & Export RVO: & Bestico BV \\
Productcode: & compost (zwarte grond) & Name producer: & 2650 AD Berkel en Rodenrijs \\
Address: & Postbus 155 & Zipcode and place: & BSF Compost \\
Foreign producer: & $\mathrm{N}$ & Relation number producer & \\
Number of samples: & 1 & Remark: & Kind of compost: \\
Barcode: & & Way of sampling: & \\
Aantal grepen: & 7 grepen van $200 \mathrm{ml}$ & &
\end{tabular}

Analysis / Research method / Executive labatory

Calcium carbonate / OWn method, volumetry, WVS-102 / LZV Calcium carbonate

$\%$ d.m.

1.0

Dry matter / Own method (execution conform NEN-EN 15934), gravimetry, WVS-003 / LZV
Dry matter
$\mathrm{kg} / \mathrm{ton}$
421

Dry matter

weight \%

42.1

Loss on ignition / Own method, loss in ignition method with correction lutum, WVS-035 / LZV Organic matter weight $\%$ d.m.

83.1

Ash weight $\%$ d.m.

16.9

Main elements / Own method, spectrofotometry, WVS-136 / LZV

Potassium

Magnesium

$\mathrm{kg} /$ ton

19.0

$\mathrm{kg} /$ ton

$<1.0$

Sodium

$\mathrm{kg} / \mathrm{ton}$

$\mathrm{kg} /$ ton

Calcium

$$
4.7
$$

1.2

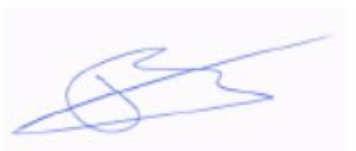

Ing. R. Thomaes

(BU Manager Dioxins)

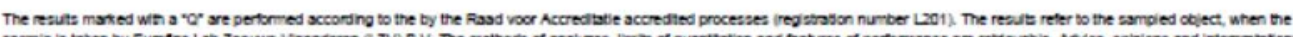

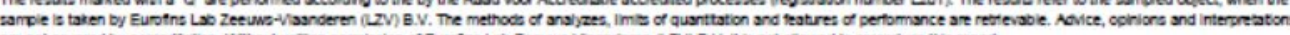

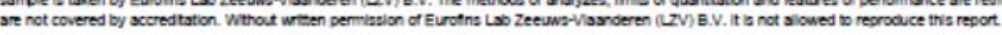




\begin{tabular}{|c|c|c|c|c|c|}
\hline$\because$ eurofins & Lab Zeeuws-Vlaanderen & $\begin{array}{l}\text { Zandbergsestraat } 1 \\
4569 \text { TC Graauw }\end{array}$ & $\begin{array}{l}\text { T } 0031114635400 \\
\text { F } 0031114635754\end{array}$ & & $\begin{array}{l}\text { E info-zulgeurofns.com } \\
\text { W wowlabzu.nl }\end{array}$ \\
\hline $\begin{array}{l}\text { Page: } \\
\text { Report number: }\end{array}$ & $\begin{array}{c}2 \text { of } 2 \\
819584-672550\end{array}$ & & & & \\
\hline Potassium & & g/kg d.m. & 45.17 & & \\
\hline Magnesium & & $\mathrm{g} / \mathrm{kg} \mathrm{d} . \mathrm{m}$. & $<2.00$ & & \\
\hline \multicolumn{5}{|c|}{$\begin{array}{l}\text { Metals / Own method (destruction conform NEN } 6961 \text { and measurement conform NEN-EN-ISO } \\
\text { 17294-2), ICP-MS, WVS-006 and WVS-071 / LZV }\end{array}$} & Samenstellingseis BG \\
\hline Arsenic & & $\mathrm{mg} / \mathrm{kg}$ d.m. & $<3.0$ & $Q$ & $<15$ \\
\hline Cadmium & & $\mathrm{mg} / \mathrm{kg}$ d.m. & 0.11 & $Q$ & $<1$ \\
\hline Chrome & & $\mathrm{mg} / \mathrm{kg}$ d.m. & $<10$ & $Q$ & $<50$ \\
\hline Copper & & $\mathrm{mg} / \mathrm{kg}$ d.m. & 19 & Q & $<90$ \\
\hline Nickel & & $\mathrm{mg} / \mathrm{kg}$ d.m. & $<3.0$ & $Q$ & $<20$ \\
\hline Lead & & $\mathrm{mg} / \mathrm{kg}$ d.m. & $<5.0$ & Q & $<100$ \\
\hline Zinc & & $\mathrm{mg} / \mathrm{kg}$ d.m. & 70 & Q & $<290$ \\
\hline Mercury & & $\mathrm{mg} / \mathrm{kg}$ d.m. & $<0.050$ & $Q$ & $<0.3$ \\
\hline Iron & & $\mathrm{mg} / \mathrm{kg}$ d.m. & 1200 & $Q$ & \\
\hline Sulfur & & $\mathrm{mg} / \mathrm{kg}$ d.m. & 8000 & & \\
\hline \multicolumn{6}{|c|}{$\begin{array}{l}\text { Nitrogen and Phosphate / Own method (execution based on NEN } 7434 \text { and o-NEN 7435), } \\
\text { continuous flow spectrofotometry, WVS-022 / LZV }\end{array}$} \\
\hline Nitrogen $(\mathrm{N})$ & & kg/ton & 15.73 & & \\
\hline Phosphate (P2O5) & & kg/ton & 10.25 & & \\
\hline Nitrogen $(\mathrm{N})$ & & g/kg d.m. & 37.41 & & \\
\hline Phosphate (P2O5) & & g/kg d.m. & 24.36 & & \\
\hline \multicolumn{6}{|c|}{ Nutrients / Own method, spectrofotometry, WVS-118 / LZV } \\
\hline Ammonium & & kg/ton & 2.69 & & \\
\hline Chlorine $(\mathrm{Cl})$ & & $\mathrm{mg} / \mathrm{kg}$ d.m. & 7500 & & \\
\hline \multicolumn{6}{|c|}{ pH / Own method, electrochemistry, WVS-149 / LZV } \\
\hline $\mathrm{pH}$ & & & 7.1 & & \\
\hline \multicolumn{6}{|c|}{ Specific weight / Own method, gravimetry / LZV } \\
\hline EC & & $\mathrm{uS} / \mathrm{cm}$ & 1700 & & \\
\hline
\end{tabular}

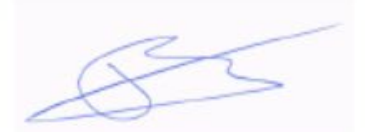

Ing R. Thomaes

(BU Manager Dioxins)

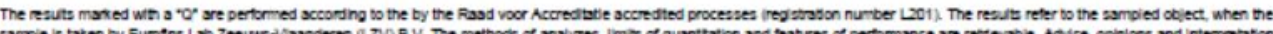

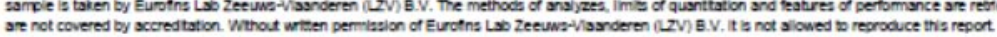




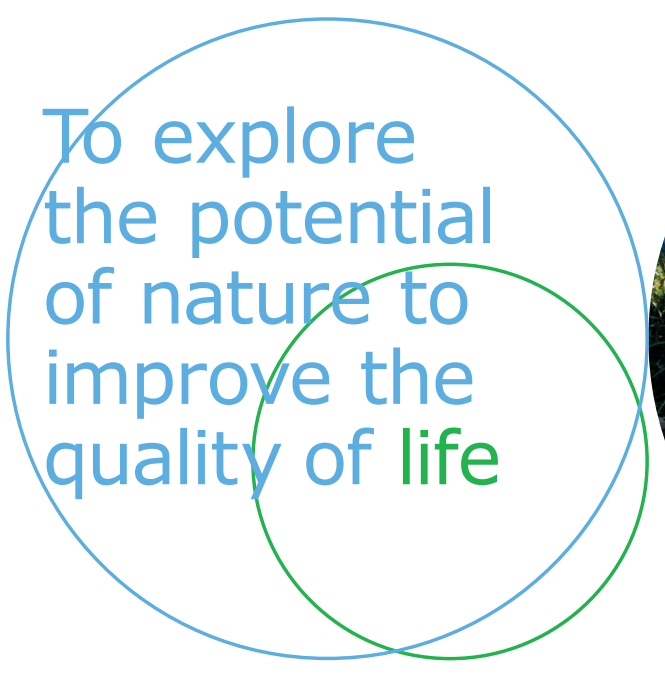

Corresponding address for this report:

Wageningen University \& Research | Field Crops Edelhertweg 1

PO Box 430, 8200 AK Lelystad

T । (+31) 320291111

www.wur.eu/fieldcrops

Report WPR-816

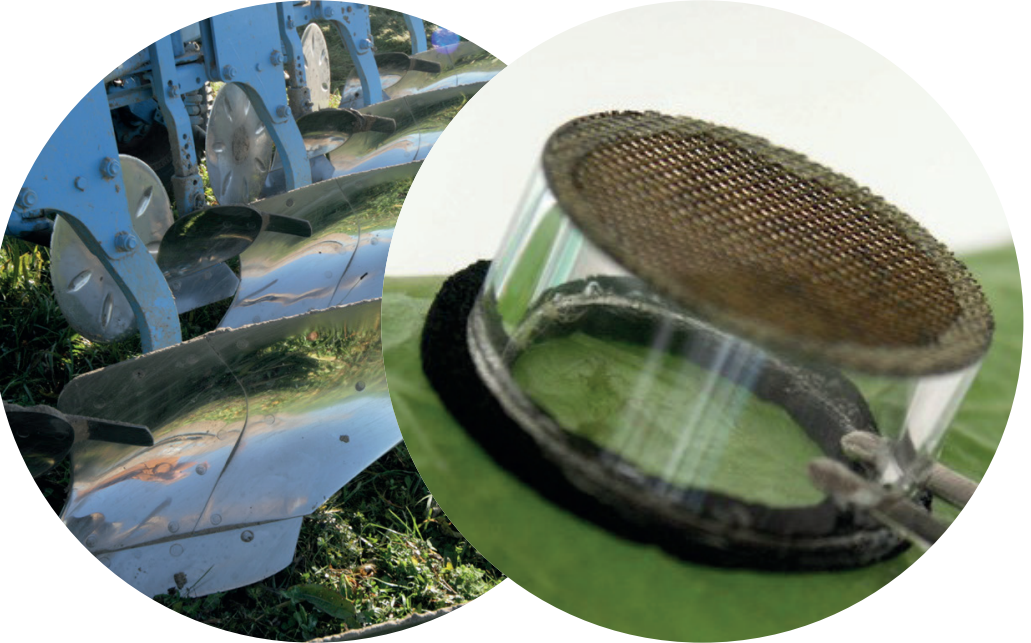

The mission of Wageningen University \& Research is 'To explore the potential of nature to improve the quality of life'. Within Wageningen University \& Research, nine specialised research institutes of the foundation Wageningen Research have joined forces with Wageningen University to help answer the most important questions in the domain of healthy food and living environment. With approximately 30 locations, 6,500 members of staff and 10,000 students, Wageningen University \& Research is one of the leading organisations in its domain worldwide. The integral approach to problems and the cooperation between the various disciplines are at the heart of the unique Wageningen Approach. 